한우 초음파생체단층촬영 형질에 대한 유전모수 추정과 씨수소 선발에

관한 연구

노승희 $^{1 *} \cdot$ 김창엽 $^{1} \cdot$ 원유석 $^{1} \cdot$ 박철진 $^{1} \cdot$ 이성수 $^{1} \cdot$ 이정규 $^{2}$

${ }^{1}$ 농협중앙회 한우개량사업소, ${ }^{2}$ 경상대학교 응용생명과학부

\title{
Studies on Genetic Parameter Estimation and Sire Selection to Ultrasound Measurement Traits of Hanwoo
}

\author{
Seung Hee Roh ${ }^{1}$, Chang Yeup Kim ${ }^{1}$, You Seog Won ${ }^{1}$, Chel Jin Park ${ }^{1}$, Sung Soo Lee ${ }^{1}$ and Jeng Gyu Lee ${ }^{2}$ \\ ${ }^{1}$ Hanwoo Improvement Center. NACF, ${ }^{2}$ Division of Applied Life Science, GyeongSang National University
}

\begin{abstract}
This study is conducted to use the real-time ultrasound measurement data of Hanwoo as basic data being available to improvement. We used the ultrasound measurement data of 1,125 heads of performance tested cattle and the carcass data after castrating at about 12 months of age, fattened to 30 months, and then sold. For 921 heads of progeny tested cattle, we used test data and slaughter data. Heritabilities of ultrasound data for longissimus muscle area and backfat thickness measured at 12 months of age were estimated as 0.57 and- 0.41 , respectively, and at 24 months of age, it was 0.57 and- 0.60 , respectively, with high heritability. However, in estimation value of heritability containing ultrasound measurement for percent intramuscular fat, it showed low and medium heritability as 0.14 at 12 months of age and 0.22 at 24 months of age for each. The longissimus muscle area, backfat thickness, and percent intramuscular fat of ultrasound measure traits and longissimus muscle area, backfat thickness, marbling score of carcass traits genetic correlation of at 12 months of age were estimated as $0.616,0.544,0.501$, respectively and at 24 months of age, it showed high genetic correlation as $0.894,0.937,0.263$, respectively. As a result of ranking correlation between selection index by using weight, carcass traits at 12 months of age and selection index based on ultrasound measurement data which has high genetic correlation, in data of ultrasound measurement at 12 months of age, it showed high ranking correlation as that selection index of young bull was 0.140 and that of proven bull was 0.843 .
\end{abstract}

(Key words : Hanwoo, Real-time ultrasound measurement, Heritability, Genetic correlation, Rank correlation)

\section{서 론}

한우는 우리나라의 농경사회를 대표하는 역용종으로 많이 이용되 어져 왔다. 그러나, 지금은 역용으로 이용하기 보다는 육용으로 많 이 개량되어 주요 동물성단백질 공급원으로 중요한 부분을 차지하 고 있다. 한우는 역용종에서 육용종으로 개량하기 시작한지는 그리 역사가 오래되지 않았다. 1967년 한우개량협의회가 설립되면서 역 우에서 육우로 개량목표가 설정되어 개량을 시작하게 되었으며, 그 동안 많은 개량효과를 가져왔지만, 세계적인 다른 육우와 경쟁하기 에는 증체량과 육질에서 아직 부족한 점이 여전히 존재하고 있다. 이를 개선하고자 우수 종축 선발에 관하여 많은 연구가 진행중에 있다. DNA 정보를 바탕으로 우수한 유전자 형질을 이용하여 선발
하는 방법과 초음파생체단층촬영을 이용하여 선발하는 방법 등에 대하여 연구를 수행하고 있는데 그 중에서도 후자의 방법은 현재 육우에서 종축선발에 적용하고 있다. 미국 앵거스 협회에서는 초음 파 생체단층촬영 시기를 12 개월령에 유전적으로 비교가 가능하고, 유전적 선발반응을 가장 잘 반영될 수 있는 시기로 이 시기에 많이 측정하고 있다(Hassen 등, 2004).

한우에서도 초음파생체단층촬영 기술을 도입하여 한우 비육우를 촬영하여 사양관리 및 출하시기 조정 등에 접목하고 있으나, 아직 개량에 활용하고 있지 못하고 있다. 이에 본 연구에서는 초음파생 체단층촬영 자료를 바탕으로 유전모수를 추정하여 개량에 활용할 수 있는 방법을 모색하고자 실시하였다.

\footnotetext{
* Corresponding author: Seung Hee Roh, Hanwoo Improvement Center, NACF, Seosan, Chungnam, 356-831, Korea, Tel: 041-661-4600,
} Fax: 041-663-8637, E-mail: jinsweet@empal.com 


\section{재료 및 방법}

\section{1. 공시재료}

본 연구는 당대검정우 1,125 두를 대상으로 초음파생체단층촬영, 6 개월령, 9개월령, 12 개월령 체중 및 6개월령과 12 개월령 사이의 일당증체량 자료와 당대검정 종료 후 후보씨수소 선발에서 탈락한 개체를 농협 안성목장에서 12 개월령에 거세한 후 30 개월령까지 비 육 출하하여 도체성적을 조사한 자료를 이용하였다. 그리고, 후대 검정우는 921두에 대하여 당대검정우의 성적조사 방법과 동일하게 적용하여 측정한 자료와 후대검정 종료 (24개월령) 후 비육 출하하 여 도체성적을 조사하였다.

\section{2. 조사항목}

본 연구에서 조사된 형질로는 초음파 측정형질, 성장형질, 도체 형질을 이용하였으며, 초음파 측정형질은 배최장근단면적, 등지방두 께 그리고, \%지방함량을 이용하였고, 성장형질로는 6개월령 체중, 9 개월령 체중, 12 개월령 체중과 6 개월령과 12 개월령 사이의 일당 증체량을 이용하였다. 도체형질은 배최장근단면적, 등지방두께, 근 내지방도, 도체중 그리고, 도축 후 등심에 대하여 조지방 함량을 분석한 자료를 도체형질에 포함시켜 분석하였다.

\section{(1) 초음파 측정 형질}

초음파 측정은 Pie Medical사의 Falco-100, Aquila 기기를 이 용하여 12 개월령과 24 개월령을 대상으로 배최장근단면적, 등지방 두께, $\%$ 지방 함량에 대하여 측정하였다. 배최장근단면적은 제 13 늑 골과 제 1 요추 사이를 제 13 늑골과 평행하게 측정하였고, 지방함량

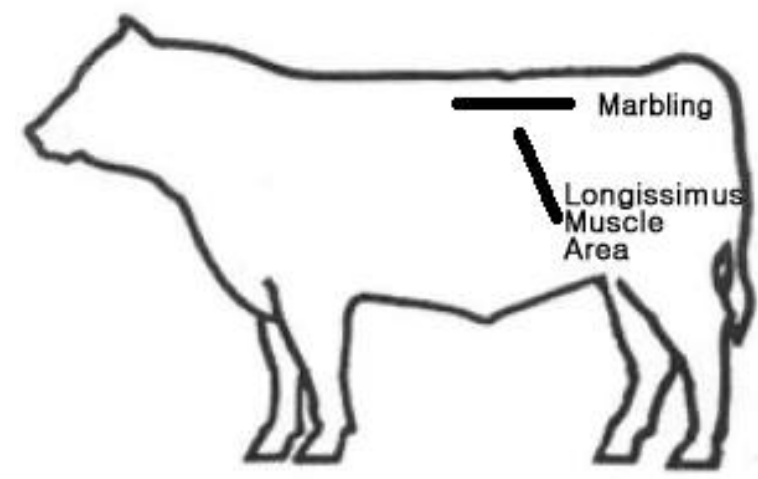

Fig. 1. Ultrasound measurement position.

추정을 위한 근내지방도는 Fig. 1 과 같이 제 13 늑골과 제 1 요추 사 이를 확인할 수 있게 흉추와 나란히 측정 하였다. 등지방두께는 배 최장근단면적을 촬영한 이미지에서 $3 / 4$ 지점에서 피하지방층 두께 를 측정하여 판독하였다. \%지방 함량 수치는 12 개월령에 눈으로 판독하기에는 제한적이므로 초음파 기기의 $\%$ 지방함량 수치를 이 용하였다.

\section{(2) 성장형질}

본 연구에 이용된 성장형질로는 6 개월령, 9 개월령, 12 개월령 체 중과 6 개월령에서 12 개월령 사이의 일당증체량을 이용하였으며, 각 형질별 보정체중은 다음과 같다.

6개월령 보정 체중 $=$ 입식시 체중 +

$$
\frac{\text { (개시시 체중 }- \text { 입식시 체중 })}{(\text { 개시시 일령 }- \text { 입식시 일령 })} \times(180-\text { 입식시 일령 })
$$

Table 1. Number of animals by test method, location, dam age and test year-season

\begin{tabular}{|c|c|c|c|c|c|c|c|}
\hline Test Method & No. & Location $^{\mathrm{a}}$ & No. & Dam Age & No. & Test Year-season & No. \\
\hline Performance Test & 1,125 & $\mathrm{HIC}$ & 512 & 1 & 40 & 2003 Fall & 286 \\
\hline \multirow[t]{9}{*}{ Progeny Test } & 921 & $\mathrm{HIF}$ & 1,534 & 2 & 258 & 2004 Spring & 280 \\
\hline & & & & 3 & 438 & 2004 Fall & 213 \\
\hline & & & & 4 & 356 & 2005 Spring & 338 \\
\hline & & & & 5 & 284 & 2005 Fall & 404 \\
\hline & & & & 6 & 224 & 2006 Spring & 298 \\
\hline & & & & 7 & 162 & 2006 Fall & 227 \\
\hline & & & & 8 & 113 & & \\
\hline & & & & 9 & 70 & & \\
\hline & & & & $\geq 10$ & 101 & & \\
\hline Total & 2,046 & & 2,046 & & 2,046 & & 2,046 \\
\hline
\end{tabular}

\footnotetext{
${ }^{\mathrm{a}}$ HIC : Hanwoo Improvement Center, HIF : Hanwoo Improvement Farm.
} 
9 개월령 보정 체중 $=6$ 개월령 체중 +

$$
\begin{gathered}
\frac{(9 \text { 개월령 체중 }-6 \text { 개월령 체중 })}{(9 \text { 개월령 측정일령 }-6 \text { 개월령 측정일령 })} \\
\times(270-6 \text { 개월령 측정일령 })
\end{gathered}
$$

12 개월령 보정 체중 $=9$ 개월령 체중 +

$$
\frac{(12 \text { 개월령 체중 }-9 \text { 개월령 체중 })}{(12 \text { 개월령 측정일령 }-9 \text { 개월령 측정일령 })}
$$

일당증체량 $=\frac{(12 \text { 개월령 체중 }-6 \text { 개월령 체중 })}{(12 \text { 개월령 일령 }-6 \text { 개월령 일령 })}$

\section{(3) 도체형질}

축산물등급판정소에서 실시하는 등급판정기준에 의거 실시한 냉 도체중, 배최장근단면적, 등지방두께, 근내지방도를 이용하였다.

조지방 함량은 도축 후 제 1 요추 한마디 (약 $1 \mathrm{~kg}$ )를 절개하여 국 립 축산과학원에서 실시하고 있는 조지방 함량 분석방법으로 분석 한 결과치를 활용하였다.

\section{3. 통계적 분석방법}

\section{(1) 유전모수 추정}

본 연구에서 조사한 초음파 측정형질, 성장형질, 도체형질에 대 하여 각 형질의 상가적 유전효과에 대한 유전모수 및 육종가 추정 을 위하여 다형질 혼합모형을 이용하여 분석하였다.

$$
Y=X b+Z a+e
$$

여기서, $Y$ 는 각 형질의 관측치(초음파 측정형질, 성장형질, 도체형 질)에 대한 벡터, $X$ 는 고정효과에 대한 계수행렬, $b$ 는 고정효과에 대한 추정치 벡터로써 당·후대구분, 년도계절, 생산지, 어미연령이며, 초음 파 측정형질인 경우 초음파 측정일령, 성장형질인 경우 개시일령, 도 체형질은 도축일령에 대한 공변량 벡터, $Z$ 는 개체에 대한 임의효과에 관한 계수 행렬, $a$ 는 개체에 대한 육종가 벡터, $e$ 는 각 형질에 대한 임 의 오차 벡터이다.

유전모수 추정은 EM-REML algorism을 바탕으로 한 REMLF90 (Misztal, 2001)를 이용하여 분석하였으며, 각 분산값의 차이가 $10^{-11}$ 이하로 수렴 될 때까지 반복추정하였다. 당대검정에 서 유전모수 추정 분석 시 이용된 혈통자료는 총 8,806 두이고, 근 교된 개체수는 543 두로 근친된 개체에 대한 평균 근교계수는 0.0187 였다. 총 8,806 두 중에서 아비와 어미를 모두 알고 있는 개 체 6,556 두, 개체만 알고 있는 두수 1,953 두, 어미만 알고 있는 개 체 29두, 그리고 아비만 알고 있는 개체는 268 두 였다.

후대검정에 대한 혈통자료는 총 4,140 두이고, 근교된 개체수는 180 두로 근친된 개체에 대한 평균 근교계수는 0.0219 였다. 혈통자 료에서 아비와 어미를 모두 알고 있는 개체 2,818 두, 개체만 알고 있는 두수 1,235 두, 어미만 알고 있는 개체 10 두, 그리고, 아비만
알고 있는 개체는 77 두 였다.

\section{결과 및 고찰}

\section{1. 각 형질별 일반성적}

한우 당대검정 (12개월령)과 후대검정 (24개월령)에 대한 각 형질 별 평균과 표준편차는 Table 2와 같다.

초음파 측정형질은 평균 368 386일령 (12개월령)에 측정한 배최 장근단면적, 등지방두께, 근내지방도의 \%지방 함량 자료에서 당대 검정우는 $52.5 \mathrm{~cm}^{2}, \quad 3.34 \mathrm{~mm}, \quad 2.59$ 였으며, 후대검정우에서는 $46.91 \mathrm{~cm}^{2}, 3.85 \mathrm{~mm}, 3.28$ 로 당대검정우에서 배최장근단면적이 조 금 넓으며, \%지방함량에서 후대검정이 높게 나타났다. 그리고, 성 장형질에서는 비거세우인 당대검정우가 높았으며, 도체형질은 30 개 월령까지 비육출하한 후보씨수소 선발 탈락우에서 높게 나타났다.

Crews 등 (2002)은 육우에 대하여 12개월령때 생체단층촬영을 활용하여 배최장근단면적을 측정한 결과 거세우, 수소, 경산우에서 각각 $64.60 \mathrm{~cm}^{2}, 64.71 \mathrm{~cm}^{2}, 51.14 \mathrm{~cm}^{2}$ 로 나타났으며, 등지방두께 는 각각 $10.10 \mathrm{~mm}, 3.06 \mathrm{~mm}, 4.36 \mathrm{~mm}$ 으로 보고하였다. 한우는 12 개월령에 평균적으로 육우보다 배최장근단면적이 적으며, 등지방 두께는 더 얇은 것으로 나타났다.

\section{2. 유전모수 추정}

\section{(1) 유전력}

본 연구에서 초음파 측정형질, 성장형질, 도체형질을 이용하여 12 개월령에 측정한 자료와 24 개월령에 측정한 자료에 대하여 (공) 분산성분, 잔차(공)분산 및 유전력을 분석한 결과는 Table 3 에 제 시하였다.

12 개월령의 초음파 측정형질인 초음파 측정 배최장근단면적, 등 지방두께, \%지방함량에 대한 유전력은 각각 $0.57,0.41,0.14$ 로 추 정되었는데, Hassen 등 (2004)은 초음파 배최장근단면적에서 0.45 로 보고 하였으며, 본 연구결과가 조금 높은 결과를 보였다. Hassen 등 (2003)은 초음파 측정형질인 \%지방 함량에 대하여 RRM (Random Regression Model)을 이용하여 유전력을 분석한 결과 28 주령 소에 대하여 $0.32,63$ 주령에 대하여 0.53 으로 보고하 였으나, 12개월령 (52주)에 대한 한우의 유전력은 0.14로 Hassen 등(2003)이 보고한 자료보다 낮은 추정치를 보였다. 이는 육우 선 발체계에서 \%지방함량을 이용하여 선발에 활용하기 때문에 측정자 및 판독의 정확도에서 기인한 결과라고 사료되어진다. Stelzleni 등 (2002)은 Brangus 육우에 대하여 초음파 생체단층촬영을 실시하여 배최장근단면적, 등지방두께, \%지방 함량 그리고 12 개월령 체중에 대하여 유전모수를 추정한 결과 유전력이 각각 $0.31,0.26,0.16$ 그리고 0.53 으로 보고하였는데 한우에 비하여 배최장근단면적과 등 지방두께에서 낮게 추정되었고 근내지방도는 유사한 결과를 보였 다. 
Table 2. Basic statistics for real-time ultrasound, weight and carcass traits in Hanwoo

\begin{tabular}{|c|c|c|c|c|c|c|c|c|}
\hline \multirow{2}{*}{ Traits $^{\mathrm{a}}$} & \multicolumn{4}{|c|}{ Performance Test } & \multicolumn{4}{|c|}{ Progeny Test } \\
\hline & $\mathrm{N}$ & Mean \pm STD & Min & Max & $\mathrm{N}$ & Mean \pm STD & Min & Max \\
\hline UAGE (day) & 831 & $368.97 \pm 21.23$ & 299 & 415 & 241 & $386.98 \pm 23.455$ & 306 & 435 \\
\hline $\operatorname{ULMA}\left(\mathrm{cm}^{2}\right)$ & 831 & $52.5 \pm 6.039$ & 35.5 & 72.8 & 241 & $46.81 \pm 5.205$ & 33.3 & 72.4 \\
\hline $\mathrm{UBF}(\mathrm{mm})$ & 831 & $3.34 \pm 0.878$ & 1.2 & 7.7 & 241 & $3.85 \pm 1.169$ & 1.5 & 8.8 \\
\hline UIMF (\%) & 811 & $2.59 \pm 1.158$ & 0.1 & 8.27 & 241 & $3.28 \pm 0.682$ & 1.62 & 5.34 \\
\hline AGE (day) & 1125 & $190.63 \pm 16.899$ & 150 & 232 & 921 & $181.99 \pm 21.572$ & 120 & 244 \\
\hline WT6 (kg) & 1125 & $186.42 \pm 23.729$ & 111 & 260 & 921 & $175.39 \pm 31.032$ & 86 & 260 \\
\hline WT9 (kg) & 1124 & $266.26 \pm 26.726$ & 180.9 & 357.3 & 919 & $244.34 \pm 25.741$ & 150.7 & 331.6 \\
\hline WT12 (kg) & 1120 & $373.54 \pm 34.185$ & 256.8 & 473 & 916 & $327.13 \pm 29.146$ & 233.7 & 460.8 \\
\hline ADG (day) & 1124 & $1.07 \pm 0.118$ & 0.5 & 1.4 & 918 & $0.83 \pm 0.122$ & 0.4 & 1.5 \\
\hline SAGE (day) & 267 & $930.74 \pm 45.405$ & 704 & 1,090 & 914 & $729.28 \pm 31.341$ & 666 & 857 \\
\hline $\operatorname{IMF}(\%)$ & . & . & . & . & 542 & $10.58 \pm 4.025$ & 2.22 & 25.21 \\
\hline CWT (kg) & 267 & $440.48 \pm 39.254$ & 320 & 581 & 911 & $355.71 \pm 37.701$ & 230 & 488 \\
\hline $\operatorname{LMA}\left(\mathrm{cm}^{2}\right)$ & 267 & $88.7 \pm 9.945$ & 65 & 116 & 911 & $76.96 \pm 8.231$ & 42 & 111 \\
\hline $\mathrm{BF}(\mathrm{mm})$ & 267 & $14.07 \pm 5.517$ & 5 & 39 & 911 & $4.73 \pm 5.36$ & 0.3 & 35 \\
\hline MS & 267 & $4.21 \pm 1.786$ & 1 & 8 & 911 & $3.28 \pm 1.699$ & 1 & 8 \\
\hline
\end{tabular}

${ }^{a}$ UAGE : The age of ultrasound-measured, ULMA : Ultrasound-measured longissimus muscle area, UBF : Ultrasound-measured backfat thickness, UIMF : Ultrasound-measured intramuscular fat, AGE: The age of start tested, WT6: Adjusted weight at 6 months of age, WT9 : Adjusted weight at 9 months of age, WT12: Adjusted yearling weight, ADG : Average daily gain, SAGE : Slaughter age, IMF : Intramuscular fat, CWT : Carcass weight, LMA : Longissimus muscle area, BF : Backfat thickness, MS : Marbling score

Table 3. Components of variance, heritability among real-time ultrasound, growth and carcass traits in Hanwoo

\begin{tabular}{|c|c|c|c|c|c|c|}
\hline \multirow{2}{*}{ Traits } & \multicolumn{3}{|c|}{12 months of age } & \multicolumn{3}{|c|}{24 months of age } \\
\hline & $\sigma_{\mathrm{a}}{ }^{2}$ & $\sigma_{\mathrm{e}}^{2}$ & $h^{2}$ & $\sigma_{a}{ }^{2}$ & $\sigma_{\mathrm{e}}^{2}$ & $\mathrm{~h}^{2}$ \\
\hline ULMA & 17.79 & 13.53 & 0.57 & 32.5 & 24.55 & 0.57 \\
\hline UBF & 0.32 & 0.47 & 0.41 & 5.83 & 3.83 & 0.60 \\
\hline UIMF & 0.08 & 0.52 & 0.14 & 0.20 & 0.70 & 0.22 \\
\hline WT6 & 137.5 & 323.5 & 0.30 & 116.90 & 411.70 & 0.22 \\
\hline WT9 & 227.5 & 351.5 & 0.39 & 80.40 & 526.0 & 0.13 \\
\hline WT12 & 327.7 & 502.1 & 0.39 & 112.0 & 665.0 & 0.14 \\
\hline $\mathrm{ADG}$ & 0.003 & 0.01 & 0.25 & 0.001 & 0.011 & 0.08 \\
\hline IMF & 9.62 & 5.10 & 0.65 & 11.50 & 3.20 & 0.78 \\
\hline CWT & 431.1 & 849.1 & 0.34 & 365.30 & 746.00 & 0.33 \\
\hline LMA & 27.9 & 43.9 & 0.39 & 25.60 & 38.10 & 0.40 \\
\hline $\mathrm{BF}$ & 6.98 & 7.00 & 0.50 & 6.02 & 5.84 & 0.51 \\
\hline MS & 1.50 & 1.40 & 0.52 & 1.20 & 1.10 & 0.52 \\
\hline
\end{tabular}


Crews 등(2002)은 12개월령 수소에 대하여 유전력은 초음파 측정 배최장근단면적, 등지방두께에서 각각 $0.61,0.50$ 으로 보고하 였으며, Kemp 등(2002)은 도체중, 배최장근단면적, 등지방두께, 근내지방도와 초음파 측정형질인 초음파 측정 배최장근단면적, 등 지방두께, \%지방함량에 대한 유전력은 각각 $0.48,0.45,0.35$, $0.42,0.29,0.39$ 그리고 0.51 로 보고하였다. 본 연구와 초음파 등 지방두께는 비슷한 경향치를 보였으나, 초음파 측정 \%지방함량은 본 연구결과에서 유전력이 낮게 추정되었다.

성장형질인 6 개월령체중, 9 개월령체중, 12 개월령체중, 일당증체 량에 대한 12 개월령의 유전력은 각각 $0.30,0.39,0.39,0.25$ 로 추 정되었으며, 24 개월령은 각각 $0.22,0.13,0.14,0.08$ 로 추정되었는 데 최 등 (2005)이 6개월령 체중과 12 개월령 체중의 유전력이 각 각 $0.50,0.27$ 로 보고한 자료보다 낮은 결과를 보였다. 당대검정과 후대검정을 실시하기 시작한 시기인 1988년에서 1991년까지 조사 한 후대검정 성적을 바탕으로 신 등 (1991)이 6개월령 체중과 일당 증체량에 대한 유전력이 각각 $0.52,0.29$ 로 보고하였는데, 본 연구 결과 보다 월등히 높은 결과치를 나타내었다. 이는 검정사업의 초 창기로 혈통자료의 정립이 완전하지 않은 시기였기 때문인 것으로 사료된다.

일본화우의 당대검정과 후대검정자료를 이용하여 분석한 Oikawa 등 (2000)은 9개월령 체중, 13.5 개월령 체중 및 일당증체량에서 유 전력이 각각 $0.38,0.37$ 및 0.20 으로 발표하였는데, 본 연구결과와 비슷한 경향치를 보였다.

도체형질인 도체중, 배최장근단면적, 등지방두께, 근내지방도의 12 개월령 유전력은 각각 $0.34,0.39,0.50,0.52$ 로 나타났으며, 24 개월령 유전력은 각각 $0.33,0.40,0.51,0.52$ 로 추정되었다. Lee
등 (2001)은 도체중, 도체율, 배최장근단면적, 등지방두께, 근내지방 도에서 각각 $0.221,0.335,0.342,0.310,0.362$ 로 보고하였는데, 본 연구결과 도체중과 배최장근단면적에서 비슷한 경향치를 보였으 나, 등지방두께와 근내지방도에서 낮은 결과를 보였다. Pariacote 등(1998)은 American Shorthorn에서 등지방두께, 배최장근단면적, 근내지방도에서 각각 $0.46,0.97,0.88$ 로 한우 도체형질의 유전력 보다 높게 추정되었으며, 도축 후 조지방 함량에 대한 유전력은 12 개월령에서 $0.65,24$ 개월령은 0.78 로 추정되었다.

\section{(2) 유전상관 및 표현형 상관}

Table 4 는 12 개월령 한우의 초음파 측정형질, 성장형질, 도체형 질간의 유전상관과 표현형상관을 나타낸 표이다. 초음파 측정 배최 장근단면적과 도축 후 배최장근단면적, 초음파 측정 등지방두께와 도체 등지방두께, 초음파 측정 \%지방함량과 근내지방도에서 유전 상관이 각각 $0.616,0.544,0.501$ 로 비교적 높은 정의 유전상관을 보였으며, 초음파 측정 배최장근단면적과 성장형질 (WT6, WT9)간 에는 $0.228,0.473$ 으로 정의 유전상관으로 추정되었다. 초음파 측 정 등지방두께와 일당증체량간의 유전상관은 0.466 으로 나타났고, $\%$ 지방함량과 성장형질 $(\mathrm{WT} 9, \mathrm{ADG})$ 간에는 $-0.366,-0.075$ 로 모 두 부의 상관관계로 나타났다.

Crews 등 (2002)은 12개월령 수소에 대하여 초음파 측정 배최 장근단면적과 도체 배최장근단면적간의 유전상관은 0.71 로 높은 상 관으로 나타났다고 보고하였는데, 본 연구결과와 비슷한 경향치를 보였다. 그러나, Greiner 등 (2003)은 12개월령 초음파 측정형질과 24 개월령 후 도체성적간의 비교한 자료에서 제 12 늑골 부분의 지방 함량과 도축 후 지방함량 그리고, 초음파 측정 배최장근단면적과

Table 4. Genetic and phenotypic correlations among real-time ultrasound, growth and carcass traits at 12 months of age in Hanwoo

\begin{tabular}{crrrrrrrrrrrr}
\hline Traits & ULMA & UBF & UIMF & WT6 & WT9 & WT12 & ADG & IMF & CWT & LMA & \multicolumn{1}{c}{ BF } & MS \\
\hline \hline ULMA & & 0.185 & -0.106 & 0.228 & 0.473 & 0.401 & 0.415 & -0.071 & 0.273 & 0.616 & -0.013 & 0.022 \\
UBF & 0.172 & & -0.133 & 0.079 & 0.258 & 0.308 & 0.466 & 0.141 & 0.354 & -0.031 & 0.544 & 0.049 \\
UIMF & -0.098 & -0.058 & & -0.257 & -0.366 & -0.171 & -0.075 & 0.462 & -0.007 & 0.26 & -0.158 & 0.501 \\
WT6 & 0.259 & 0.268 & 0.028 & & 0.854 & 0.815 & 0.369 & -0.126 & 0.710 & 0.295 & 0.213 & -0.289 \\
WT9 & 0.409 & 0.170 & -0.081 & 0.566 & & 0.936 & 0.710 & -0.034 & 0.698 & 0.347 & 0.163 & -0.105 \\
WT12 & 0.464 & 0.129 & -0.146 & 0.439 & 0.850 & & 0.834 & 0.041 & 0.825 & 0.366 & 0.129 & -0.055 \\
ADG & 0.41 & -0.026 & -0.215 & 0.016 & 0.470 & 0.751 & & 0.159 & 0.640 & 0.325 & -0.002 & 0.166 \\
IMF & -0.205 & 0.241 & 0.284 & -0.038 & -0.043 & 0.045 & 0.074 & & 0.116 & 0.050 & 0.162 & 0.896 \\
CWT & 0.300 & 0.226 & -0.034 & 0.511 & 0.588 & 0.708 & 0.357 & 0.188 & & 0.419 & 0.306 & -0.032 \\
LMA & 0.347 & -0.071 & -0.001 & 0.256 & 0.268 & 0.325 & 0.152 & 0.146 & 0.530 & & -0.283 & 0.194 \\
BF & 0.093 & 0.549 & 0.065 & 0.182 & 0.207 & 0.207 & 0.030 & 0.186 & 0.326 & -0.006 & & -0.074 \\
MS & -0.057 & 0.168 & 0.201 & 0.048 & -0.001 & -0.003 & 0.033 & 0.730 & 0.115 & 0.225 & 0.029 & \\
\hline
\end{tabular}

Note : Genetic correlations are above and phenotypic correlations are below the diagonal. 
도축 후 배최장근단면적 간의 유전상관이 각각 $0.89,0.86$ 이라 하 여 본 결과 보다 유전상관이 다소 높게 나타났다.

초음파 측정형질이 육우선발에 있어서 유전적 선발반응이나 선 발의 정확도를 높이고, 도체 EPD(Expected Progeny Difference) 를 추정할 수 있는 잠재적인 중요성이 있다고 Crews 등 (2001)이 보고하였는데, 본 연구는 초음파 측정형질과 도체형질의 유전상관 이 높은 정의상관을 보여 Crews 등 (2001)이 보고한 자료와 같이 선발에 이용하였을 경우 정확도가 높아질 수 있을 것이라 사료 된다.

성장형질인 12 개월령 체중과 도체중간의 유전상관과 표현형상관 은 각각 $0.825,0.708$ 로 높은 상관을 보였는데, 이는 육성기때의 성숙도가 향후 도체형질에도 많은 영향을 미치는 것을 알 수 있다.

도체중과 배최장근단면적, 등지방두께, 근내지방도에서 유전상관 이 각각 $0.419,0.306,-0.032$ 로 나타났으며, 배최장근단면적과 등지방두께, 근내지방도 간의 유전상관은 $-0.283,0.194$ 로 각각 추정되었다. 근내지방도는 도체중과 배최장근단면적, 등지방두께에 서 큰 상관을 보이지 않았으나, 조지방 함량은 0.896으로 높은 유 전상관을 보였다.

24개월령에 대한 각 형질별 유전상관과 표현형상관은 Table 5에 제시를 하였는데, 초음파 측정 형질인 배최장근단면적, 등지방두께 와 도체형질인 배최장근단면적, 등지방두께에서 유전상관이 각각 $0.894,0.937$ 으로 높은 정의 유전상관을 보였으며, \%지방함량과 근내지방도 간에는 0.263 으로 낮은 유전상관을 보였다. 도체중과 배최장근단면적, 등지방두께에서 유전상관이 각각 $0.481,0.336$
로 추정되었는데 노 등 (2004)이 보고한 $0.651,0.138$ 와 다소 차이를 보였다. 배최장근단면적과 근내지방도간의 유전상관은 0.109 로 낮은 정의상관으로 추정되어 신 등 (1991)과 박 등 (2002)이 보고한 $0.06,0.02$ 보다 높은 정의상관을 보였다.

\section{(3) 순위상관}

후보씨수소와 보증씨수소 선발지수와 초음파 형질을 이용한 선발 지수간의 순위상관 결과는 Table 6과 같다.

본 연구에서 사용된 선발지수는 가축개량협의회(한우분과위원회) 에서 씨수소 선발 시 이용되고 있은 지수식을 이용하였다.

후보씨수소를 선발하는 선발지수와 보증씨수소 선발지수와 초음 파 형질간의 유전상관이 높은 12 개월령체중, 초음파 배최장근단면 적, \%지방함량을 접목하여 초음파 선발지수 간의 순위상관을 실시 한 결과 후보씨수소 선발지수와 보증씨수소 선발지수, 초음파 형질 선발지수는 각각 $0.331,0.140$ 로 추정되었고, 보증씨수소 선발지 수와 초음파 형질 선발지수는 0.843 으로 높은 정의상관으로 추정 되었다.

후대검정을 실시한 24개월령 성적을 바탕으로 분석한 자료에서 후보씨수소 선발지수와 보증씨수소 선발지수간에는 모두 부의상관 을 보였으며, 보증씨수소 선발지수와 초음파 형질 선발지수 간에는 0.259 로 추정되었다.

따라서, 향후 12 개월령 초음파 측정형질을 선발지수에 활용하여 씨수소를 선발 하였을 경우 지금의 보증씨수소 선발지수 체계와 높 은 상관이 있으므로 초음파 측정형질을 이용하여 우수한 씨수소 선

Table 5. Genetic and phenotypic correlations among real-time ultrasound, growth and carcass traits at 24 months of age in Hanwoo

\begin{tabular}{crrrrrrrrrrrr}
\hline Traits & ULMA & UBF & UIMF & WT6 & WT9 & WT12 & ADG & IMF & CWT & LMA & \multicolumn{1}{l}{ BF } & \multicolumn{1}{c}{ MS } \\
\hline \hline ULMA & & -0.063 & 0.655 & 0.494 & 0.372 & -0.029 & 0.525 & 0.518 & 0.66 & 0.894 & -0.064 & -0.069 \\
UBF & 0.225 & & -0.275 & 0.061 & 0.047 & 0.23 & -0.329 & -0.198 & 0.459 & -0.17 & 0.937 & -0.105 \\
UIMF & -0.068 & -0.008 & & 0.537 & 0.496 & -0.238 & 0.884 & 0.907 & 0.152 & 0.607 & -0.151 & 0.263 \\
WT6 & 0.345 & 0.167 & 0.031 & & 0.925 & 0.434 & 0.462 & 0.424 & 0.417 & 0.298 & 0.183 & -0.307 \\
WT9 & 0.372 & 0.217 & 0.024 & 0.648 & & 0.633 & 0.544 & 0.424 & 0.378 & 0.113 & 0.142 & -0.257 \\
WT12 & 0.434 & 0.256 & 0.008 & 0.467 & 0.804 & & -0.018 & -0.314 & 0.402 & -0.256 & 0.158 & -0.478 \\
ADG & 0.207 & 0.08 & -0.003 & -0.244 & 0.217 & 0.573 & & 0.776 & 0.05 & 0.397 & -0.177 & 0.088 \\
IMF & 0.165 & 0.187 & -0.006 & -0.006 & -0.002 & 0.084 & 0.077 & & 0.076 & 0.434 & -0.096 & 0.474 \\
CWT & 0.609 & 0.377 & -0.022 & 0.509 & 0.583 & 0.704 & 0.353 & 0.221 & & 0.481 & 0.336 & -0.304 \\
LMA & 0.695 & 0.062 & -0.148 & 0.269 & 0.269 & 0.324 & 0.124 & 0.159 & 0.523 & & -0.207 & 0.109 \\
BF & 0.168 & 0.804 & 0.085 & 0.193 & 0.222 & 0.226 & 0.039 & 0.182 & 0.347 & 0.003 & & -0.122 \\
MS & 0.210 & 0.035 & -0.087 & 0.068 & 0.022 & 0.023 & 0.041 & 0.717 & 0.136 & 0.214 & 0.032 & \\
\hline
\end{tabular}

Note : Genetic correlations are above and phenotypic correlations are below the diagonal. 
Table 6. Rank correlations among the selection index for young bull, proven bull and ultrasound-measured in Hanwoo

\begin{tabular}{cccc}
\hline Index $^{\mathrm{a}}$ & YBSI & PBSI & USI \\
\hline \hline YBSI & & $0.331^{* *}$ & $0.140^{* *}$ \\
PBSI & $-0.236^{* *}$ & & $0.843^{* *}$ \\
USI & $-0.676^{* *}$ & $0.259^{* *}$ & \\
\hline
\end{tabular}

Note : The rank correlations of 12 months of age are above and 24 months of age are blow the diagonal.

** : $\mathrm{p}<0.01$

${ }^{a}$ YBSI (Young bull selection index) :(Yearling weight $\left.\mathrm{EBV} \times 2\right)+$ Marbling score EBV, PBSI (Proven bull selection index) : (Longissimus muscle area EBV) $-($ Backfat thickness EBV) + (Marbling score EBV $\times 6$ ), USI (Ultrasound-measured selection index) : (Ultrasound-measured longissimus muscle area EBV)-(Ultrasound-measured Backfat thickness EBV) $+($ Ultrasound-measured intramuscular fat $\mathrm{EBV} \times 6$ )

발이 가능할 것으로 사료되나, 씨수소 선발 시 초음파 측정형질만 가지고 선발하였을 경우 선발의 정확도의 문제가 발생하므로 더 많 은 연구가 선행되어야 될 것으로 사료된다.

$$
\text { 요 약 }
$$

본 연구는 한우초음파생체단층촬영 자료를 이용하여 한우개량을 위한 기초자료로 활용코자 실시하였다. 당대검정우 1,125 두에 대하 여 초음파생체단층 촬영한 자료와 검정성적자료 및 12 개월령에 거 세한 후 30 개월령까지 비육 후 출하하여 도체성적을 조사한 자료 를 이용하였으며, 후대검정우는 921 두에 대한 검정성적자료와 도체 성적자료를 이용하였다.

12 개월령에 측정한 초음파생체단층 촬영 배최장근단면적과 등지 방두께의 유전력은 각각 $0.57,0.41$ 로 추정되었으며, 24 개월에서는 각각 $0.57,0.60$ 으로 고도의 유전력을 보였다. 그러나, 초음파 측정 $\%$ 지방함량 유전력 추정치에서는 12 개월령과 24 개월령에서 각각 $0.14,0.22$ 로 저·중도의 유전력을 보였다. 12 개월령에 초음파생체 단층 촬영한 배최장근단면적, 등지방두께, $\%$ 지방함량과 도체형질의 배최장근단면적, 등지방두께, 근내지방도의 유전상관은 각각 0.616 , $0.544,0.501$ 로 추정되었고, 24 개월령에서는 각각 $0.894,0.937$, 0.263 으로 높은 유전상관을 보였다. 12 개월령에 측정한 초음파 측 정 \%지방함량과 근내지방도에서 높은 유전상관으로 추정되었는데, 이는 24 개월령에서는 환경적요인 (사양기술 등)에 의해 영향을 많 이 받은 것으로 사료되며, 선발에 활용할 경우 24 개월령 측정치 보 다는 12 개월령 측정치를 이용하는 것이 더 바람직할 것으로 사료 된다. 12 개월령 체중과 도체형질을 이용하여 씨수소를 선발하는 선 발지수와 이와 유전상관이 높은 초음파생체단층촬영 자료를 바탕으 로 선발하는 선발지수간의 순위상관을 분석한 결과 12 개월령에 초 음파생체단층 촬영한 자료에서 후보씨수소 선발지수는 0.140 , 보 증씨수소 선발지수는 0.843 으로 높은 순위상관을 보였다.

본 연구결과 실시간으로 배최장근단면적, 등지방두께, 근내지방도 와 같은 도축하지 않아도 도체성적을 파악할 수 있는 초음파생체단
층 촬영 기술의 장점을 이용하여 선발에 활용한다면 근내지방도는 24 개월령에 측정하는 것보다 12 개월령에 측정하는 것이 더 효율적 이라고 사료되어지며, 향후 초음파생체단층기술에 관한 더 많은 연 구를 통하여 종축선발에 활용한다면 씨수소의 조기선발이 가능할 것으로 사료된다.

\section{인 용 문 헌}

Crews, D. H. and Kemp, R. A. 2001. Genetic parameters for ultrasound and carcass measures of yield and quality among replacement and slaughter beef cattle. J. Anim. Sci. 79:30083020 .

Crews, D. H. and Kemp, R. A. 2002. Genetic evaluation of carcass yield using ultrasound measures on young replacement beef cattle. J. Anim. Sci. 80:1809-1818.

Crews, D. H., Shannon, N. H., Crews, R. E. and Kemp, R. A. 2002. Weaning, yearling and preharvest ultrasound measures of fat and muscle area in steers, bulls and heifers. J. Anim. Sci. 80:2817-2824.

Greiner, S. P., Rouse, G. H., Wilson, D. E., Cundiff, L. V. and Wheeler, T. L. 2003. Prediction of retail product weight and percentage using ultrasound and carcass measurements in beef cattle. J. Anim. Sci, 81:1736-1742.

Hassen, A., Wilson, D. E. and Rouse, G. H. 2003. Estimation of genetic parameters for ultrasound-predicted percentage of intramuscular fat in Angus cattle using random regression models. J. Anim. Sci. 81:35-45.

Hassen, A., Wilson, D. E., Rouse, G. H. and Tait, R. G. 2004. Partitioning variance of growth in ultrasound longissimus muscle area measures in Angus bulls and heifers. J. Anim. Sci. 82:1272-1279.

Lee, D. H. and Bertrand, J. K. 2001. Comparison of Genetic 
Parameter Estimates for Carcass Traits According to Modeling with REML and Gibbs sampling in Korean Cattle. J. Anim. Sci. \& Technol. (kor.) 43(1):23-34.

Misztal, I. 2001. BLUPF90 family of programs. http://nce.ads. uga.edu/ ignacy/newprograms.html. Accessed Dec 3, 2001.

Oikawa, T., Sanehira, T., Sato, K., Mizoguchi, Y., Yamamoto, H. and Babk, M. 2000. Genetic parameter for growth and carcass traits of Japanese Black (Wagyu) Cattle. Anim. Sci. 71: 59-64.

Pariacote, F., Van Vleck, L. D. and Hunsley, R. E. 1998. Genetic and phenotypic parameters for carcass traits of American Shorthorn beef cattle. J. Anim. Sci. 76:2584-2588.

Stelzleni, A. M.. Perkins, T. L., Brown, A. H., Pohlman, F. W., Johnson, Z. B. and Sandelin, B. A. 2002. Genetic parameter estimates of yearling live animal ultrasonic measure- ments in Brangus cattle. J. Anim. Sci. 80:3150-3153.

노승희, 김병우, 김효선, 민희식, 윤호백, 이득환, 전진태, 이정규. 2004. 한 우의 도체형질 유전모수 추정을 위한 REML과 Bayesian via Gibbs Sampling 방법의 비교 연구. 동물자원지. 46(5):719-728.

박철진. 2002. 한우의 성장형질과 도체형질에 대한 유전상관 추정. 동물자 원지 44(6):685-692.

신언익, 이문걸, 이득환, 1991. 한우의 종모우 평가방법에 관한 연구. I . 증체 및 도체 형질에 대한 유전 모수 추정. 한축지. 33(12):817- 822. 최연호, 윤호백, 최성복, 정흥우. 2005. 세가지 도축 종료 시점을 공변량으 로 하는 한우 도체형질에 대한 유전능력 분석모형. 동물자원지. 47(5):703-710.

(접수일자 : 2009. 11. 10/ 수정일자: 2009. 12. 16/ 채택일자 : 2010. 1. 13) 